\title{
POPULATION COMPOSITION OF MIGRANTS IN SUBURBS OF RIGA METROPOLITAN AREA
}

Janis Krumins ${ }^{1,}$ Msc. Geogr.; Toms Skadins², Bsc. Geogr.

1,2 University of Latvia

\begin{abstract}
Internal migration has been important in transforming the metropolitan regions of Central and East European countries over the past two decades. Suburban settlements are in the process of quick change, and the most obvious manifestation of those changes is expressed in socio-spatial restructuring. Previous research reveals that a close relationship exists between socio-spatial stratification and migration patterns but, despite the widespread nature of suburbanization in the post-socialist countries, this relationship has been insufficiently studied. Aim of the present study was to examine the characteristics of the usual residents and suburban inmigrants in the Riga metropolitan area (RMA). The analysis was based on individual level data from the recently released 2011 census round. These statistics are the most reliable data source of population composition in the post-socialist countries. The characteristics of population subgroups of the inner and the outer suburban ring of the RMA, which are with and without migration experience, were analysed using binary logistic regression models. The study has found some evidence of differential mobility behaviour regarding individual sociodemographic characteristics and geographic features. Thus, the research contributes to a better understanding of post-socialist suburbanization by clarifying the population subgroups behind the shift to the suburbs.
\end{abstract}

Key words: Riga metropolitan area, population composition, geographical mobility, internal migration, suburbanization.

JEL code: J61, R190

\section{Introduction}

Latvia, similarly to other post-socialist countries in Central and Eastern Europe, can be considered as a typical case of suburbanization driven expansion of metropolitan areas. This process has been studied in relation to post-socialist transformation by urban geographers in many countries of the region (Sykora L., Cermak D., 1998; Tammaru T. et al., 2004; Nuissl H., Rink D., 2005; Ourednicek M., 2007; Krisjane Z., Berzins M., 2012; Szabo T. et al., 2014). In Latvia, several studies have addressed the intensive development of suburban settlement and changes in population composition, and mobility behaviour in the Riga metropolitan area (Berzins M., Krisjane Z., 2008; Puzulis A., Skinkis P., 2009; Berzins M., 2011a). However, the role of migration processes in the forming of population composition, has been insufficiently studied, and mostly in relation to everyday mobility (e.g. Krisjane Z., et al., 2012; Burgmanis G., 2014). Therefore, this article sheds light on changes driven by the process of residential suburbanization within the Riga metropolitan area (RMA), by drawing particular attention to changes in specific areas of influence of Riga based on its proximity (inner and outer suburban rings).

Both suburban rings (especially the inner) have a very strong functional connection with the core city. The centre of the metropolitan area provides work, study, leisure time and other opportunities for those living in the outskirts, whereas suburbia provides an opportunity of having a private house in a pleasant environment, while still being able to maintain a passable distance between a place of residence and work. Thus, suburbia can be considered as an area of privilege that often attracts migrants who represent population groups with higher economic potential; therefore, contributing to the emergence of processes related to socio-spatial differentiation. This phenomenon has been widely studied in the context of post-socialist cities and urban regions (Ruoppila S., Kahrik A., 2003; Brade I., et al., 2009; Sykora L., 2009; Kahrik A., Tammaru T., 2010; Marcinczak S., et al., 2015), and it is certain that mobility plays crucial role in shaping population composition. Especially in suburban areas that attract in-migrants from both - core city 
and periphery, thus contributing to high mobility intensity. Therefore, it is important to determine the effect of mobility on the population composition.

Two research questions were provided in order to fulfil the aim of this article:

1) Are demographic, socio-economic and locational characteristics significant for migrants to relocate to suburbia?

2) What population groups are the most inclined to engage in the process of migration?

\section{Data and methods}

Geographical population mobility is closely related to various demographical, political and socioeconomic factors that further influence population composition and the development of settlement patterns. In this article, demographic and socio-economic characteristics of residents of the RMA are analysed, using 2011 Population Census dataset, while the binary logistic regression was applied as the main method of analysis.

Binary logistic regression is a method of the econometric analysis (Greene H.W., 2003) that was used to divide the 2011 Population Census dataset of the RMA into two main sub-samples migrants and non-migrants. The Census data can be considered as the most reliable and the most accurate source to determine population characteristics. Regrettably, 2011 Census provides limited information regarding internal migration. Therefore, migrants and non-migrants were divided according to their mobility to their current place of residence from any other municipality of Latvia from April 2010 to April 2011. In total, the dataset consisted of 234793 residents of the inner suburban ring, and 181643 residents of the outer suburban ring, which represented $20.1 \%$ of the population of Latvia.

Migrants were placed as a group of reference and compared to non-migrants for various demographic and socio-economic indicators in order to determine a likelihood for specific population composition groups to participate in the process of internal migration. Regression coefficients were presented as the main statistical determinants in this study. In cases where the result was positive, it meant that the likelihood to participate in migration was higher than for the reference group (e.g. male residents).

Regression coefficients were estimated for demographic indicators such as gender, age group, ethnicity and family status, and socio-economic indicators such as a sector of economic activity, socio-economic status, and the level of education. In addition, two suburban rings were also compared to determine the significance of geographical location in order to shape the characteristics of internal migration.

In total, 8 sets of characteristics were taken into consideration - gender, age group, ethnicity, family status, education, economic activity sector, socio-economic status and geographical proximity. For all 8 characteristics, the reference group (Table 1) was given value 1 , and all other residents representing different status, were given 0 . Therefore, a linear regression model was created, that compared the characteristics between mobile and non-mobile residents.

Gender, age group, ethnicity, family status and education were characteristics derived from the Census questionnaire without any changes. However, economic activity sector, socio-economic status and geographic proximity were not originally asked to residents of Latvia. These updated characteristics incorporate other values. Firstly, economic activity sector was merged into 3 categories. Originally, residents had to answer their sector according to NACE-2 classification (Eurostat, 2008). Thus, updated primary sector incorporated agriculture, forestry and fishing from 
this classification. Secondary sector represented those of mining, quarrying and manufacturing sectors. Tertiary sector consisted of residents working fields related to services and supply.

Secondly, socio-economic status consisted of 4 categories - high, upper-middle, lower-middle and low. These categories were derived from ISCO-08 classification (ILO, 2016). High status was given to managers and professionals. Upper-middle status was allocated to those working as technicians, associate professionals and clerical support workers. Lower-middle status was given to craft and related trades workers, and plant and machine workers/assemblers. Finally, the lower class was associated with agricultural, forestry and fishery workers, services and sales workers and representatives of elementary occupations. Several studies of the post-socialist context have used this division in relation to socio-spatial segregation (Musterd S., 2005; Marcinczak S., et al., 2015; Krisjane Z., et al., 2015). Lastly, geographical proximity characteristic was derived from residents' place of residence. Municipalities located in the inner ring were given 1 , and those of the outer ring, were merged into an opposite category.

\section{Results and discussion}

\section{Economic and demographic heterogeneity of Riga metropolitan area}

Internal migration flows in Latvia are oriented from its peripheral parts to the centre - capital city and its area of influence; the Riga metropolitan area. Whereas, within the RMA the most characteristic flows are directed from the capital city to its suburban area - Pieriga region. RMA is not considered as administrative territorial unit but has more functional purpose instead. This means, that its area of impact can change and adjust to political, economic and other type of fluctuations. This research uses the RMA borders that were refined in 2012 (RD PAD, 2012), when its estimated area was 7297.6 sq.km ( $11.3 \%$ of total area of Latvia). Also, the municipalities of RMA consisted of more than 1 million inhabitants, which constituted approximately $50.4 \%$ of all residents of Latvia in 2011. Such pattern of population formation shows not only the high population density but also the formation of economic activity.

The Riga metropolitan area differs from planning regions of Latvia in higher economic and sociodemographic conditions and rates (except Riga and Pieriga, which are included in RMA). However, the area of Riga metropolitan region cannot be regarded as an entirely homogeneous unit within its borders. It consists of three parts (Figure 1) - the core (city of Riga); the inner suburban ring (closer municipalities), and the outer suburban ring (outermost municipalities).

The municipalities of inner ring are located close to Riga - the economic centre of Latvia. Furthermore, they allow for migrants to change their living conditions from an apartment block house to a private house. The proximity of Riga allows thousands of migrants to relocate outside of Riga but still to maintain their workplace within an acceptable range of everyday commuting. On the other hand, municipalities that are in the outer ring of the RMA lack such living conditions and the proximity of commuting. According to Central Statistics Bureau (CSB 2018), the population in the inner ring has increased by $12.2 \%$, while it has decreased by $15.2 \%$ in the outer ring from 2000 to 2017.

Economic characteristics also differ between both suburban rings. Personal income tax revenues allow one to evaluate socio-economic differences between the residents. If they are higher, then the municipality has greater opportunities to develop social infrastructure and, thereby, attract more migrants from Riga or other regions. In 2016, the average revenue of personal income tax in the municipalities of the inner ring was 780 euros per one inhabitant, whereas the same tax 
collected by the municipalities of the outer ring was only 547 euros (RDIM, 2017). Such differences influence not only the economic development of these areas but also affect the process of inmigration and out-migration, and further encourage the change of population composition pattern. The empiric part of this article stresses the connection of mobility behaviour and demographic/socio-economic characteristics in both rings taken together, thus emphasizing the RMA as an economically powerful functional unit.

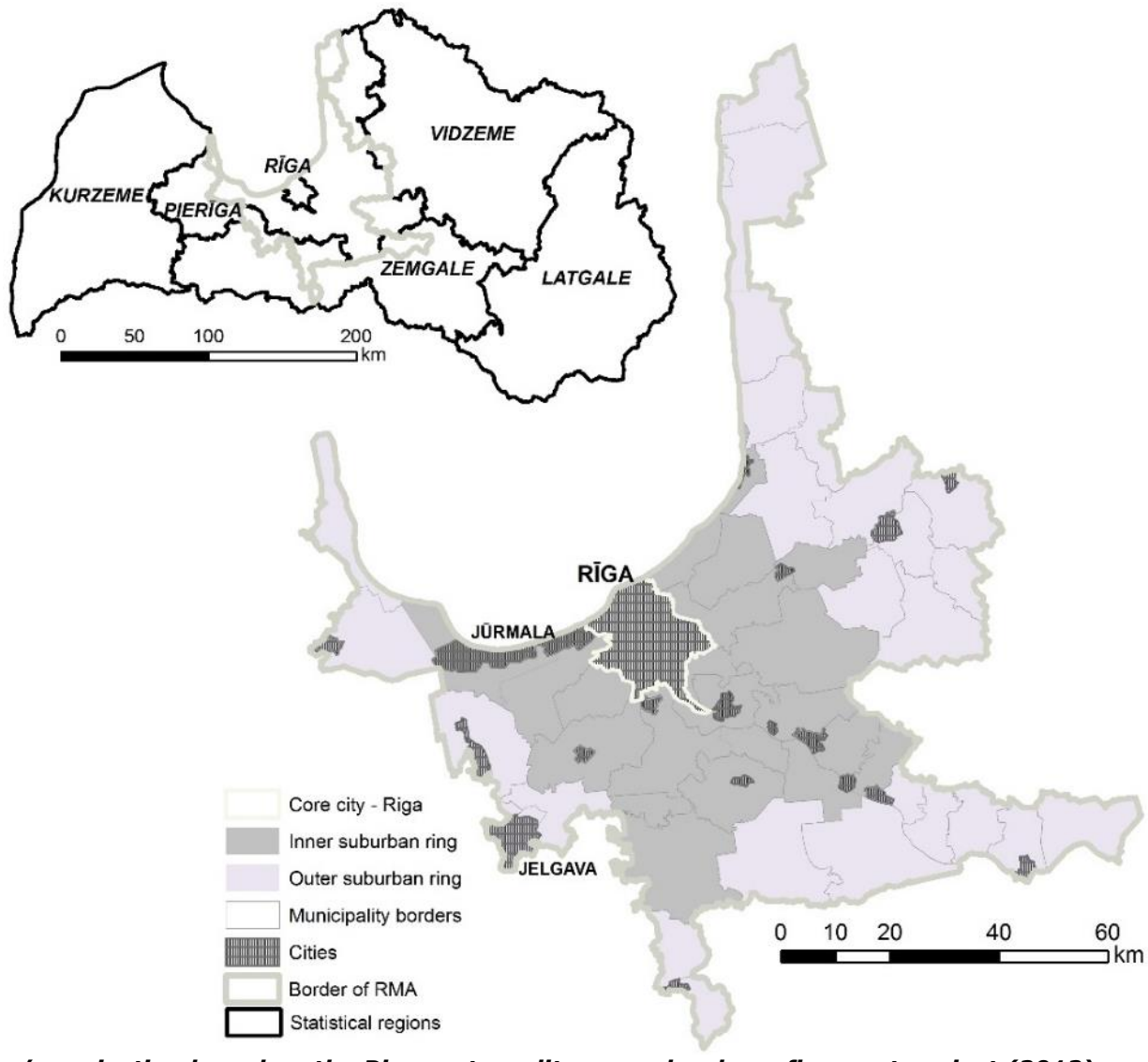

Source: author's projection based on the Riga metropolitan area border refinement project (2012)

Fig. 1. Structure of Riga metropolitan area

\section{Population composition of migrants of Riga metropolitan area}

Internal migration can trigger changes in population composition, when the territory receives inmigrants who differ from the long-time residents in their socio-demographic and socio-economic characteristics. As a result, in-migrants integrate within the population of their new residence area, and a new population composition, physical and social settlement structure starts to form through processes of suburbanization. After regularly gaining or losing residents at the expense of migration, a region becomes functionally different, and it starts to adapt to the new social standards.

The Population Census results show that a bigger probability to engage in the internal migration process was characteristic of the residents of younger age groups, males, people with Latvian ethnicity, and higher education (Table 1 ). The binary regression analysis showed that these demographic indicators are significant in shaping the characteristics of population mobility and composition. As stated above, mobile residents represented migrants from 2010 to 2011. This period included the presence of the economic crisis. Nevertheless, the results did show that the demographic factors such as gender, age, education level and ethnicity were significant to describe 
differences in population composition between in-migrants and long-time resident, while socioeconomic factors such as the economic activity sector and category showed that they could not be included as significant ones in shaping the nature of internal migration. Similar research about the migration in Latvia had been conducted (Berzins M., 2011b), including the RMA, where demographic factors also resulted as more significant than economic factors.

Residents within the age group from 25 to 34 were more inclined to participate in the process of internal migration, surpassing 15 to 24 year olds. Previous studies (Berzins M., 2011b; Krisjane Z., et al., 2012) claimed that the level of mobility tended to decrease with age. In this case, the results could be explained with the level of education, which was considerably higher for 25 to 34 year olds. From all residents of the RMA inner and outer ring, $25.9 \%$ of those with higher education were from this age group, while only $5.1 \%$ were within the age group from 15 to 24 . In addition, a considerable share of members of the older age group represented the highest socioeconomic category. About one fourth of this category were 24 to 35 year olds, while only $5 \%$ represented the youngest working age group. Such results could be explained with traditional migration motives. Residential conditions and attractive environment conditions are usually the driving factors that influence migration flows to suburbia. On the contrary, work and study opportunities are dominant in migration flows to cities (Berzins M., 2011b). Residents within the age group from 25 to 34 were simultaneously the most economically stable and the most mobile group.

Latvians were more prone to participate in the process of internal migration than people with another ethnicity. This could be explained with the difference in age. The average age for Latvians was lower than for minorities, although the presence of compatriots can also be regarded as a significant stimulus to migrate or stay. Respectively, higher mobility of minorities is characteristic in the territories which are lower in the share of titular nation (Tammaru T., et al., 2011; Ivlevs A., 2013). 
Population composition of mobile and non-mobile residents in Riga Metropolitan area. Binary logistic regression analysis. Reference group: non-mobile residents

\begin{tabular}{|c|c|}
\hline \multicolumn{2}{|c|}{ Mobile residents $(N=8954)(\beta)$} \\
\hline \multicolumn{2}{|c|}{ Gender (ref.: male) } \\
\hline Female & $-0.25^{*}$ \\
\hline \multicolumn{2}{|c|}{ Age group (ref.: 15-24) } \\
\hline 25-34 & $0.281^{*}$ \\
\hline $35-44$ & $-0.46 *$ \\
\hline 45-64 & $-1.036^{*}$ \\
\hline \multicolumn{2}{|c|}{ Ethnicity (ref. Latvian) } \\
\hline Russian & $-0.212 *$ \\
\hline Other minorities & $-0.232 *$ \\
\hline \multicolumn{2}{|c|}{ Family status (ref.: married) } \\
\hline Single & $0.222 *$ \\
\hline Divorced & $0.447 *$ \\
\hline Widowed & $0.37 *$ \\
\hline \multicolumn{2}{|c|}{ Education level (ref.: Higher education) } \\
\hline $\begin{array}{l}\text { Vocational secondary } \\
\text { education }\end{array}$ & $-0.222 *$ \\
\hline Secondary & $-0.315^{*}$ \\
\hline Vocational & $-0.393^{*}$ \\
\hline Middle-school (Grade 9) & $-0.624 *$ \\
\hline Elementary (Grade 4) & $-0.687^{*}$ \\
\hline \multicolumn{2}{|c|}{ Economic activity sector (ref.: tertiary) } \\
\hline Secondary & -0.016 \\
\hline Primary & 0.108 \\
\hline \multicolumn{2}{|c|}{ Socio-economic status (ref.: high) } \\
\hline Upper-middle & -0.016 \\
\hline Lower-middle & -0.079 \\
\hline Low & 0.008 \\
\hline \multicolumn{2}{|c|}{ Geographical proximity (ref.: inner suburban ring) } \\
\hline Outer suburban ring & $-0.251 *$ \\
\hline
\end{tabular}

* - statistically significant with a probability of $95 \%$

Source: author's calculations based on Population Census 2011 data

Divorced, widowed and single residents had higher probability to participate in the process of migration. Therefore, these groups tend to migrate more and to change their place of residence, while married residents relate to their place of residence in a way of their own and their family member connections with their working and study places. Mobility from suburbs to Riga can be considered as an exception. In this case, the residents of suburbia maintain a commuting distance from work to their homeplace (Berzins M., 2011b). Despite the fact, that young families with children are more characteristic to the suburban areas with a close proximity of the core city, married persons were slightly less inclined to migrate to the suburban rings of the RMA.

The residents with a higher education level were the most characteristic group to participate in the internal migration. This could be explained with two aspects - the specifics of population composition in the areas of suburbanization, and the peculiarities of the Riga city employment 
structure. In former, those migrants who relocate to suburbia from Riga are people with higher average income (Berzins M., 2011b). The latter can be referred to the migrants from the periphery of Latvia, who have migrated to the inner or the outer suburban ring. They are mostly the people with a higher level of education, because employment in the tertiary (service) sector mainly requires qualified specialists, while people with a lower education level are looking for employment in primary or secondary sectors abroad. In both cases, the suburban zone of the RMA attracts people with higher education.

A geographical factor also played significant role in shaping population composition in the RMA. The Regression analysis showed that the inner circle was more mobile, while the population composition was more stable in the outer circle. Thus, it can be concluded that the process of internal migration in the inner circle has a greater impact on population changes.

\section{Conclusions}

1) The RMA can be regarded as a unique territorial unit of Latvia. It is characterized by the concentration of economic activities in the centre city, and higher residential mobility as a process of suburbanization in outskirts of the city. Therefore, migration and differential mobility behaviour within the RMA can be associated with differences and the changeability of population composition and settlement patterns.

2) The findings of this study suggest that such demographic factors as gender and ethnicity are significant in shaping changes in population through the process of internal migration, whereas socio-economic factors such as economic activity sector and socio-economic status appear to be less significant.

3) The findings can be explained with the dynamics of suburbanization and differential mobility behaviour within the RMA. Undeniably, post-socialist suburbanization is a unique process of urban transformation, and it has been proved that economic, social and political factors play a significant role in the changeability of population composition in Latvia. Thus, the population of the suburbia of the RMA is less resistant, and is exposed to a higher level of migration, as it attracts various population subgroups such as young families with children and people from higher socio-economic categories. Nevertheless, this study has examined both inner and outer suburban rings, which are heterogeneous in terms of the intensity of suburbanization and the proximity of Riga.

4) The findings indicate that migration is characteristic of 1) males; 2) 25 to 34 years old residents; 3) persons who are separated or widowed; 4) Latvians, and 5) those with higher education.

5) Further studies regarding the role of internal migration in both rings separately would be worthwhile. In such a case, a more detailed analysis could be done about the effect of postsocialist suburbanization, and the differentiation of mobility behaviour in both research territories.

\section{Acknowledgement}

The research was supported by National Research Program Project 5.2.4 "Renewal of society through reducing the risk of depopulation, through development and strengthening links with the diaspora for the transformation of the Latvian economy". 


\section{Bibliography}

1. Berzins, M. (2011a). Iekszemes migracijas regionalas dimensijas Latvija. Latvijas Zinatnu Akademijas Vestis (A dala), Volume 65, Issue 3/4, pp. 34-54.

2. Berzins, M. (2011b). Iedzivotaju geografiskas mobilitates loma suburbanizacijas norises Latvija: doktora darbs. Riga. Faculty of Geography and Earth Sciences, University of Latvia.

3. Berzins, M., Krisjane, Z. (2008). Amenity Migration in Post-socialist Metropolis: The Case of Riga Agglomeration. In Proceedings of the Latvian Academy of Sciences. Section B. Natural, Exact, and Applied Sciences, Volume 62, Issue 1-2, pp. 71-77.

4. Brade, I., Herfert, G., Wiest, K. (2009). Recent Trends and Future Prospects of Socio-spatial Differentiation in Urban Regions of Central and Eastern Europe: A Lull Before the Storm? Cities, Volume 26, Issue 5, pp. 233-244.

5. Burgmanis, G. (2014). Commuting Patterns in Riga Agglomeration: Evidence from a Survey Analysis of Youth. Regional Formation and Development Studies, Volume 14, Issue 3, pp. 16-29.

6. CSB, (2018). Central Statistics Bureau of Latvia - Statistics Database. Retrieved: http://www.csb.gov.lv/. Access: 20.1 .2018

7. Eurostat, (2008). NACE Rev. 2 - Statistical Classification of Economic Activities in the European Community. Retrieved: http://ec.europa.eu/eurostat/documents/3859598/5902521/KS-RA-07-015-EN.PDF. Access: 22.01.2018.

8. Greene, H.W. (2003). Econometric Analysis. New Jersey, Prentice Hall.

9. ILO, (2016). International Standard Classification of Occupations - ISCO-08 Structure, Index Correspondence with ISCO-88. Retrieved: http://www.ilo.org/public/english/bureau/stat/isco/isco08/. Access: 22.01.2018.

10. Ivlevs, A. (2013). Minorities on the Move? Assessing Post-Enlargement Emigration Intentions of Latvia's Russian Speaking Minority. The Annals of Regional Science, Volume 51, Issue 1, pp. 33-52.

11. Krisjane, Z., Berzins, M. (2012). Post-socialist Urban Trends: New Patterns and Motivations for Migration in the Suburban Areas of Riga, Latvia. Urban Studies, Volume 49, Issue 2, pp. 289-306.

12. Krisjane, Z., Berzins, M., Ivlevs, A., Bauls, A. (2012). Who are the Typical Commuters in the Post-socialist Metropolis? The Case of Riga, Latvia. Cities, Volue 29, Issue 5, pp. 334-340.

13. Krisjane, Z., Berzins, M., Kratovis, K. (2015). Occupation and Ethnicity: Patterns of Residential Segregation in Riga Two Decades after Socialism. In: Tammaru, T., Marcinczak, S., Van Ham, M., Musterd, S. (eds.) Socio-economic Segregation in European Capital Cities: East Meets West, UK, Taylor and Francis Inc., pp. 287-312.

14. Kahrik, A., Tammaru, T. (2010). Population Composition in New Suburban Settlements of the Tallinn Metropolitan Area. Urban Studies, Volume 45, Issue 5-6, pp. 1055-1078.

15. Marcinczak, S., Tammaru, T., Gentile, M., Temelova, J., Novak, J., Kahrik, A., Valatka, V., Kovacs, Z., Szabo, B. (2015). Patterns of Socio-economic Segregation in the Capital Cities of Fast-Track Reforming Post-socialist Countries. Annals of the Association of American Geographers, Volume 105, Issue 1, pp. 183202.

16. Musterd, S. (2005). Social and Ethnic Segregation in Europe: Levels, Causes and Effects. Journal of Urban Affairs, Volume 27, Issue 3, pp. 331-348.

17. Nuissl, H., Rink, D. (2005). The 'Production' of the Urban Sprawl in Eastern Germany as a Phenomenon of Post-Socialist Transformation. Cities, Volume 22, Issue 2, pp. 123-134.

18. Ouredniček, M. (2007). Differential Suburban Development in the Prague Urban Region. Geografiska Annaler, Volume 89B, Issue 2, pp. 111-126.

19. Puzulis, A., Skinkis, P. (2009). Pierigas apdzivojuma strukturas izpete. Summary. Retrieved: www.rpr.gov.lv. Access: 10.12.2017.

20. RDIM, (2017). Regional Development Indicators Module - Tool for Comparing Territories. Retrieved: http://raim.gov.lv/lv/node/39. Access: 20.01.2018.

21. RD PAD, (2012). City Development Department of Riga - The Refinement Project of Boundaries of the Riga Metropolitan Area. Retrieved: http://sus.Iv/files/2012_Rigas_aglomeracijas_robezu_precizesana.pdf. Access: 10.11.2017.

22. Ruoppila, S., Kahrik, A. (2003). Socio-economic Residential Differentiation in Post-socialist Tallinn. Journal of Housing and the Built Environment, Volume 18, Issue 1, pp. 49-73.

23. Sýkora, L. (2009). New Socio-spatial Formations: Places of Residential Segregation and Separation in Czechia. Tijdschrift voor Economische en Sociale Geografie, Volume 100, Issue 4, pp. 417-435.

24. Sykora, L., Cermak, D. (1998). City Growth and Migration Patterns in the Context of 'Communist' and 'Transistory' Periods in Prague's Urban Development. Espace, Population, Societes, Volume 3, pp. 405-416.

25. Szabo, T., Szabo, B., Kovacs, Z. (2014). Polycentric Urban Development in Post-socialist Context: the Case of the Budapest Metropolitan Region. Hungarian Geographical Bulletin, Volume 63, Issue 3, pp. $287-301$.

26. Tammaru, T., Kulu, H., Kask, I. (2004). Urbanization, Suburbanization and Counter Urbanization in Estonia. Eurasian Geogaphy and Economics, Volume 45, pp. 159-176.

27. Tammaru, T., van Ham, M., Leetmaa, K., Kahrik, A., Kamenik, K. (2011). Ethnic Dimension of Suburbanization in Estonia. Journal of Ethnic and Migration Studies, Volume 39, Issue 5, pp. 845-862 